\title{
SISTEM PENUNJANG KEPUTUSAN PENENTUAN BEASISWA BERBASIS WEB PADA SMK BUDI LUHUR TANGERANG DENGAN METODE SIMPLE ADDITIVE WEIGHTING (SAW)
}

\author{
Ridwan Zakaria ${ }^{1)}$, Goenawan Brotosaputro ${ }^{2)}$ \\ ${ }^{1}$ Sistem Informasi, Fakultas Teknologi Informasi, Universitas Budi Luhur \\ 1,2 Jl. Raya Ciledug, Petukangan Utara, Kebayoran Lama, Jakarta Selatan 12260 \\ E-mail : ridwanhikaru21@gmail.com ${ }^{1)}$, goenawan.brotosaputro@budiluhur.ac.id²)
}

\begin{abstract}
Abstrak
SMK BUDI LUHUR yaitu salah satu dari banyak sekolah swasta yang masih menerapkan sistem penunjang keputusan menggunakan microsoft excel Perhitungan Manual. Dalam penelitian ini, dibuatlah sistem penunjang keputusan berbasis WEB sebagai alat bantu untuk penentuan beasiswa pada SMK BUDI LUHUR supaya mendapatkan data yang tepat dan cepat. Dapat menggunakan metode Simple Additive Weighting (SAW) dengan memanfaatkan kriteria - kriteria yang sudah ada, yakni ujian tulis, karya dan point merit. Pada metode ini menggunakan satu jenis kriteria yaitu kriteria benefi. Metode SAW menjalankan penilaian dari nilai bobot dan kriteria yang sudah ditetapkan, selanjutnya dilanjutkan dengan proses perankingan yang akan memilah alternatif terbaik dari alternatif yang ada. Hasil yang didapatkan dari program sistem penunjang keputusan ini yakni ranking siswa yang berhak memperoleh beasiswa pada SMK BUDI LUHUR dengan menghitung semua kriteria dan bobot dengan memakai metode Simple Additive Weighting (SAW). Penulis membuat rancangan aplikasi sistem penunjang keputusan memakai bahasa pemrograman PHP Native dan memakai MYSQL Front untuk database. Hasil yang sudah dibuat adalah sistem penunjang keputusan penentuan beasiswa berbasis WEB, pada SMK BUDI LUHUR TANGERANG yang akan membantu mempermudah bagi staff kurikulum dalam penentuan beasiswa dan memberikan informasi perhitungan penilaian dengan cepat, tepat dan akurat.
\end{abstract}

Kata kunci: SPK, SAW, Penentuan Beasiswa.

\section{PENDAHULUAN}

Sistem pendukung keputusan yakni suatu pendekatan untuk membantu mengambil keputusan”. Sistem pendukung keputusan memakai data, membagikan antarmuka pengguna yang gampang, dan dapat menggabungkan pemikiran pemilik keputusan.[1] SMK BUDI LUHUR berada di JL.Raden Saleh No.999 Karang Tengah Kota Tangerang Banten. Sekolah ini mengadakan program beasiswa yang di sediakan bagi siswa dan siswi yang mempunyai prestasi. Murid yang bisa mendapatkan beasiswa yakni kelas X dan XI, tidak ada batasan jumlah anak yang berhak mendapatkan beasiswa per semesternya. Selama ini penentuan beasiswa masih menggunakan microsoft excel dan sistem penilainnya terkadang masih kurang akurat. Membuat sebuah sistem penunjang keputusan untuk menentukan siswa yang mendapatkan beasiswa dengan kriteria atau kompetensi yang sudah ditentukan mengunakan metode Simple Additive Weighting (SAW). Beberapa masalah yang dihadapi SMK BUDI LUHUR TANGERANG yaitu penentuan beasiswa ini hanya bisa dilakukan oleh bagian kurikulum SMK BUDI LUHUR saja, SPK penentuan beasiswa ini hanya digunakan di SMK BUDI LUHUR, dan kriteria yang ditentukan dari SMK BUDI LUHUR adalah ujian tulis, karya, dan point merit. Metode yang digunakan dalam perancangan ini menggunakan metode Simple Additive Weighting (SAW).

konsep dasar sistem yakni sekelompok yang memiliki tujuan yang saling bersangkutan untuk mencapai tujuan bersama-sama. [2]. Informasi yakni data yang sudah diolah bagi si penerima dan memiliki keputusan yang akan datang. [3]. Sistem Penunjang Keputusan dipakai untuk menetapkan keputusan bagi komunitas, organisasi maupun perusahaan dan membantu penyelesaian masalah. [4]. Definisi Metode Simple Additive Weighting $(S A W)$ biasa juga dikenal dengan metode yang memakai cara penjumlahan terbobot. Konsep dari metode SAW yakni mencari penjumlahan terbobot dari rating kinerja pada semua alternative dan pada semua atribut. [5]. Dalam studi literatur, penelitian ini membahas tentang Penentuan mahasiswa berprestasi (mawapres) tingkat fakultas terkadang mengalami kendala disaat penilaian kriteria tertentu pada kandidat kurang memenuhi namun di kriteria lain penilaian yang diperoleh melebihi ketentuan, juga apabila data-data atau informasi yang diberikan baik oleh juri maupun data kriteria dari kandidat tidak lengkap atau mengandung ketidakpastian yang mengakibatkan ketidakpastian nilai. Oleh karena itu tujuan dari penelitian ini adalah menerapkan metode Fuzzy untuk mengatasi ketidakpastian data atau informasi dan Multi-Attribute Decision Making 
(MADM) dengan metode Simple Additive Weighting (SAW) untuk metode pengambilan keputusan dalam pemilihan mahasiswa berprestasi. Hasil dari penelitian ini adalah penerapan metode MADM untuk mendukung pengambilan keputusan dalam pemilihan mahasiswa berprestasi tingkat fakultas dengan kandidat yang berasal dari setiap program studi.[6]

Penelitian ini membahas tentang sistem

Pendukung Keputusan Pemberian Sanksi Pelanggaran Kedisiplinan Siswa Pada SMK PGRI I KEDONDONG. Pelanggaran kepada peraturan sekolah biasa dilakukan oleh para murid antara lain semakin banyaknya penyimpangan beraneka ragam norma kehidupan agama dan sosial kemasyarakatan yang tercipta dalam bentuk kurang hormat dan terkadang tidak hormat kepada guru, kurang disiplin kepada waktu dan tidak patuh terhadap tata tertib serta peraturan yang ada sekolah dan lain-lain. Penelitian ini merancang dan membuat sebuah sistem pengambil keputusan pemberian sanksi pelanggaran edisiplinan yang memiliki kemampuan analisa dimana tiap-tiap kriteria dalam faktor-faktor penilaian da alternatif yang sesuai. Dalam kasus ini murid yang mendapati melanggar peraturan akan dikenakan hukuman atau poin sehingga me bagikan output nilai intensitas prioritas yang membuat suatu sistem yang memberikan penilaian terhadap siswa. Sistem penunjang keputusan ini menolong melakukan penilaian semua murid, melakukan perusahan perubahan nilai poin dan perubahan kriteria.[7]. Untuk memperoleh data dengan teknik penelitian yang digunakan adalah wawancara, observasi, analisa dokumen, dan studi kepustakaan. Wawancara digunakan untuk meraih informasi dalam bentuk Tanya dan jawab kepada manager mengenai masalah yang hendak di riset. Observasi, Menghimpun data dengan cara datang ke tempatnya langsung untuk mendapati dokumen serta yang berkaitan dengan sistem yang akan dibuat. Analisa Dokumen, Menganalisa dokumen yang dapat dipakai untuk sistem yang dibuat nanti. Studi Kepustakaan, Metode ini memanfaatkan data selaku sumber bacaan, memakai buku, catatan kuliah, dan berbagai macam bacaan yang terdapat di internet.

\section{METODE PENELITIAN}

\subsection{Subsistem Manajemen Data}

Manajemen data memberikan data, baik dari data interna maupun eksternal. Data internal dalam aplikasi ini yakni data siswa, yang didapat dari Staff kurikulum SMK BUDI LUHUR TANGERANG Data internal digunakan untuk melakukan kegiatan dalam bentuk akses sistem. Data eksternal dalam sistem ini berupa data penilaian penentuan beasiswa berupa formulir penentuan kriteria dan bobot, laporan rekap penilaian siswa.

\subsection{Kerangka Pemikiran}

Kerangka pemikiran yang dipakai untuk riset ini dirangkum dalam gambar 2 dimulai dari perumusan masalah pada SMK BUDI LUHUR dengan menggunakan metode penelitian studi pustaka memilih sumber referensi yang terdapat dibuku yang terkait dengan masalah penentuan beasiswa. Kemudian studi lapangan dengan cara melakukan kunjungan ke SMK BUDI LUHUR untuk melakukan wawancara kepada staff kurikulum selaku pengambil keputusan pada penilaian penentuan beasiswa. Untuk memperoleh informasi mengenai proses bisnis, lalu tahap selanjutnya yakni menetapkan tujuan supaya sistem yang akan dibuat kemudian langkah pengumpulan data yakni memperoleh data data dari staff kurikulum. menentukan kriteria yang akan digunakan untuk penilaian penentuan beasiswa. Langkah selanjutnya yakni kuesioner membuat pertanyaan berdasarkan dari kriteria dan alternatif yang digunakan untuk penilaian penentuan beasiswa kemudian mendesai prototype dan model untuk mengonsep system yang ingin dibuat. Lalu langkah selanjutnya membikin laporan yang dilakukan oleh bagian staff kurikulum. Kerangka pemikiran bisa dilihat pada gambar 1 di bawah ini :

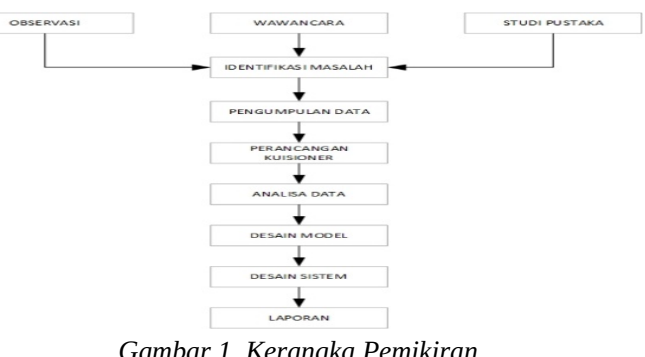

Gambar 1. Kerangka Pemikiran

\section{HASIL DAN PEMBAHASAN}

\subsection{Profil Organisasi}

Cerdas dan berbudi luhur yakni dua hal yang terpadu yang tidak bisa terpisahkan, karena kecerdasan tanpa dilandasi budi yang luhur biasanya akan digunakan untuk membodohi dan mencelakai orang lain, sebaliknya jika budi luhur tidak diimbangi kecerdasan akan menjadi sasaran kejahatan dan penindasan dari orang lain. - Drs. Djaetun. HS (Pendiri Yayasan Pendidikan Budi Luhur Cakti). Untuk mendidik tenaga trampil yang cerdas dan berbudi Luhur itu, maka pada tahun 2015 didirikan SMK BUDI LUHUR di Tangerang, beralamat di Jl. Raden Saleh No.999 Karang Tengah Kota Tangerang. Sekolah ini bertujuan menghasilkan 
tenaga-tenaga trampil atau professional di bidang multimedia dan broadcasting guna memenuhi lapangan kebutuhan lapangan pekerjaan.

\subsection{Proses Bisnis Penentuan Beasiswa}

Wakasek bidang kurikulum melakukan pengecekan data siswa yang memperoleh nilai ratarata tertinggi, top score (nilai mata pelajaran tertinggi), the best student (ranking 1), point merit tertinggi. Jika sudah, siswa yang terpilih akan di ikut sertakan dalam seleksi untuk mendapatkan beasiswa sekolah. Seleksi untuk mendapatkan beasiswa di bagi menjadi 3 tahap. Tahap 1 ujian tertulis, jika gagal maka akan langsung gugur. Tahap 2 membuat karya, Tahap 3 presentasi. Jika siswa lolos seleksi tahap 3 maka akan dibuat perhitungan berdasarkan kriteria dan bobot yang telah di tentukan. Penilaian langsung dilakukan oleh kepala sekolah, wakasek kurikulum, dan kaprog. Jika total nilai siswa sama dengan atau lebih dari 80 maka siswa di nyatakan lulus atau mendapatkan beasiswa.

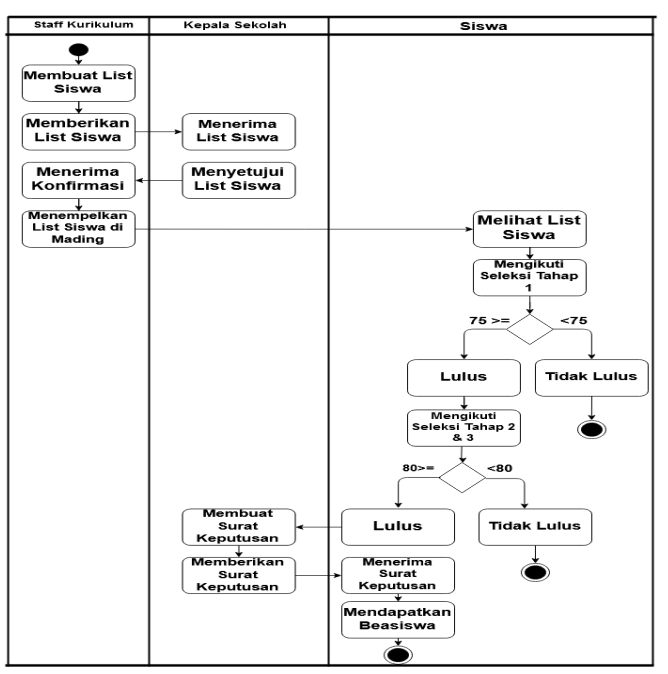

Gambar 2. Activity Diagram

\subsection{Analisa Masalah}

Berikut penjelasan dibawah ini masalah yang terdapat pada fishbone diagram dapat dilihat pada gambar 3.

1. Manusia

lambat dalam penentuan beasiswa yang disebabkan kadang terjadinya human error.

2. Metode

mengakibatkan hasil penilaian untuk penentuan beasiswa kurang cepat dan tepat yang disebabkan tidak adanya perangkingan dan pembobotan disetiap kriteria dan tidak memakai metode yang benar.

3. Proses mengakibatkan lamanya proses perhitungan nilai siswa dan kadang terjadi kesalahan karena masih memakai microsoft excel dan belum mempunyai suatu aplikasi sistem penilaian penentuan beasiswa.

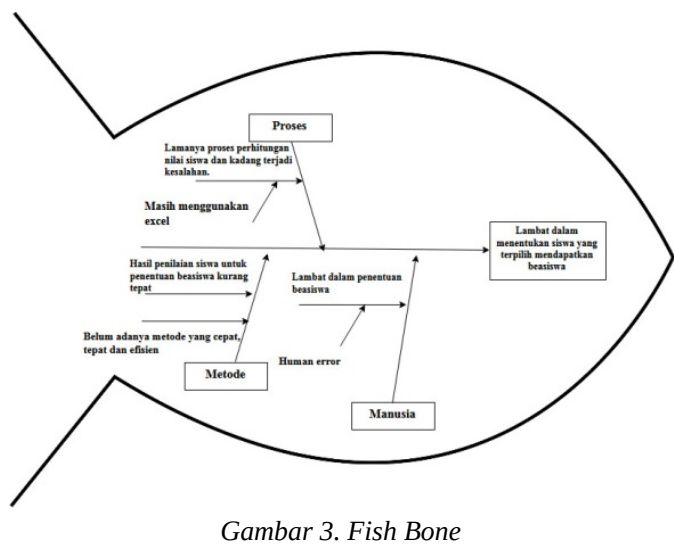

\subsection{Simple Additive Weighting (SAW)}

Metode Simple Additive Weighting (SAW) biasa juga dikenal dengan istilah metode yang memakai cara dengan penjumlahan terbobot. Konsep dari metode SAW yakni mencari penjumlahan terbobot pada setiap alternatif pada semua atribut dari rating kinerja. Proses normalisasi matriks keputusan (X) ke suatu skala yang bisa dibandingkan dengan semua rating alternatif yang ada di butuhkan oleh metode SAW. Dalam metode SAW mengharuskan pemilik keputusan menentukan atau membuat bobot bagi setiap atribut. Hasil total untuk alternatif didapatkan dengan menjumlahkan seluruh hasil dari perkalian antara rating (yang dapat dibandingkan lintas atribut) dan bobot dari tiap atribut. Rating setiap atribut haruslah bebas dimensi dalam arti sudah melewati proses normalisasi matriks sebelumnya. Normalisasi bisa di hitung seperti di bawah ini (1) :

$R_{i j}\left\{\begin{array}{l}\frac{X_{i j}}{\operatorname{Max}_{i} X_{i j}} \text { Jika j adalah atribut keuntungan } \mid \text { benefit } \mid \\ \left.\frac{\operatorname{Min}_{i} X_{i j}}{X_{i j}} \text { Jika j adalah atribut biaya } \mid \text { cost }\right)\end{array}\right.$

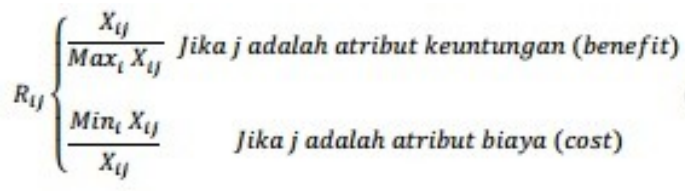

Gambar 4. Rumus Normalisasi

Keterangan :

Rij = nilai rating kinerja yang ternormalisasi $\mathrm{Xij}=$ nilai atribut yang dimiliki di setiap kriteria 
Max Xij = nilai terbesar dari di kriteriai

Min Xij = nilai terkecil di setiap kriteria

Benefit $=$ jika nilai terbesar yakni terbaik

Cost $=$ jika nilai terkecil yakni terbaik

Dimana rij yakni rating kinerja yang ternormalisasi dari alternatif $\mathrm{Ai}$ pada atribut $\mathrm{Cj}$; $\mathrm{i}=1,2, \ldots, \mathrm{m}$ dan $\mathrm{j}=1,2, \ldots, \mathrm{n}$

Nilai preferensi untuk tiap-tiap alternatif (Vi) diberikan sebagai (2):

$$
V_{i}=\sum_{j=1}^{n} w_{j} r_{i j}
$$

Keterangan :

$\mathrm{Vi}=$ rangking untuk tiap-tiap alternatif

wj = nilai bobot dari tiap-tiap kriteria

rij = nilai rating kinerja yang sudah ternormalisasi.

\section{Ketentuan Kriteria}

Berikut adalah kriteria yang dibutuhkan untuk pengambilan keputusan penentuan beasiswa pada SMK Budi Luhur Tangerang.

Tabel 1. Penentuan Kriteria

\begin{tabular}{ll}
\hline Kode Kriteria & Nama Kriteria \\
\hline KRI01 & Ujian tulis \\
KRI02 & Karya \\
KRI03 & Point Merit \\
\hline
\end{tabular}

\section{Bobot Kriteria}

Berdasarkan data yang ada, table 1 berikut ini yakni hasil dari perhitungan bobot kriteria yang sudah konsisten dan ditetapkan disetiap kriteria yang sudah ditentukan di table atas. Total bobot jika dijumlahkan tidak boleh lebih dari 100\%. Tabel 2 . Bobot Kriteria

Tabel 2. Penentuan Kriteria

\begin{tabular}{lll}
\hline Kode Kriteria & Nama Kriteria & Bobot \\
\hline KRI01 & Ujian tulis & $60 \%$ \\
KRI02 & Karya & $30 \%$ \\
KRI03 & Point Merit & $10 \%$ \\
\hline
\end{tabular}

3. Matriks Normalisasi

Berdasarkan banyaknya siswa pada SMK Budi Luhur Tangerang, maka diambil 5 (lima) siswa sebagai contoh untuk implementasi dengan metode Simple Additive Weighting (SAW) dalam penentuan beasiswa. Dimana data merupakan hasil dari rekapitulasi penilaian disetiap kriteria yang terlihat pada table berikut.

Tabel 3. Nilai Alternatif Per Kriteria

\begin{tabular}{lccc}
\hline NAMA & UJIAN TULIS & KARYA & POINTMERIT \\
\hline Arif Syarifudin & 85 & 90 & 91 \\
Tri Adi Putro & 86 & 86 & 87 \\
Dwi Laksana & 85 & 88 & 85 \\
Oka Oktarine & 87 & 85 & 87 \\
Resa Gemilang & 88 & 85 & 85 \\
\hline
\end{tabular}

Tabel 4. Penggolongan Kriteria

\begin{tabular}{llll}
\hline No & Kriteria & Trend & \\
\hline 1 & & Benefit & Cost \\
2 & Ujian Tulis & & \\
3 & Karya & & \\
\hline
\end{tabular}

Berikut merupakan perhitungan dari setiap kriteria sehingga diperoleh nilai dari masing-masing alternatif.

1.)Perhitungan Kriteria Ujian Tulis

$\mathrm{R} 12 \frac{85}{\max (85 ; 86 ; 85 ; 87 ; 88)}=\frac{85}{88}=0,965$

$\mathrm{R} 22 \frac{86}{\max (85 ; 86 ; 85 ; 87 ; 88)}=\frac{86}{88}=0,977$

$\mathrm{R} 32 \frac{85}{\max (85 ; 86 ; 85 ; 87 ; 88)}=\frac{85}{88}=0,965$

$\mathrm{R} 42 \frac{87}{\max (85 ; 86 ; 85 ; 87 ; 88)}=\frac{87}{88}=0,988$

$\mathrm{R} 52 \frac{88}{\max (85 ; 86 ; 85 ; 87 ; 88)}=\frac{88}{88}=1$

2.)Perhitungan Kriteria Karya

$$
\begin{aligned}
& \mathrm{R} 13 \frac{90}{\max (90 ; 86 ; 88 ; 85 ; 85)}=\frac{90}{90}=1 \\
& \mathrm{R} 23 \frac{86}{\max (90 ; 86 ; 88 ; 85 ; 85)}=\frac{86}{90}=0,955 \\
& \mathrm{R} 33 \frac{88}{\max (90 ; 86 ; 88 ; 85 ; 85)}=\frac{88}{90}=0,977 \\
& \mathrm{R} 43 \frac{85}{\max (90 ; 86 ; 88 ; 85 ; 85)}=\frac{85}{90}=0,944 \\
& \mathrm{R} 53 \frac{85}{\max (90 ; 86 ; 88 ; 85 ; 85)}=\frac{85}{90}=0,944
\end{aligned}
$$

3.) Perhitungan Kriteria Point Merit

$$
\begin{aligned}
& \mathrm{R} 15 \frac{91}{\max (91 ; 87 ; 85 ; 87 ; 85)}=\frac{91}{91}=1 \\
& \mathrm{R} 25 \frac{87}{\max (91 ; 87 ; 85 ; 87 ; 85)}=\frac{87}{91}=0,956 \\
& \mathrm{R} 35 \frac{85}{\max (91 ; 87 ; 85 ; 87 ; 85)}=\frac{85}{91}=0,934 \\
& \mathrm{R} 45 \frac{887}{\max (91 ; 87 ; 85 ; 87 ; 85)}=\frac{87}{91}=0,956
\end{aligned}
$$




$$
\mathrm{R} 55 \frac{85}{\max (91 ; 87 ; 85 ; 87 ; 85)}=\frac{85}{91}=0,934
$$

4. Hasil Nilai Alternatif

Tabel 5. Hasil Nilai Alternatif

\begin{tabular}{|c|c|c|c|c|}
\hline Alternative & Ujian Tulis & Karya & Pointmerit & \\
\hline Arif Syarifudin & 0,965 & 1 & 1 & 1 \\
\hline Tri Adi Putro & 0,977 & 0,955 & & 0,956 \\
\hline Dwi Laksana & 0,965 & 0,977 & & 0,934 \\
\hline Oka Oktarine & 0,988 & 0,944 & & 0,956 \\
\hline Resa Gemilang & 1 & 0,944 & & 0,934 \\
\hline Bobot & 0,6 & 0,3 & 0,1 & \\
\hline
\end{tabular}

Arif Syarifudin

$=\{(0,6$ X 0,965) $+(0,3$ X 1) $+(0,1 \times 1)\}$

$=(0,579+0,3+0,1)=0,979$

Tri Adi Putro

$0,956)\}$

$=\{(0,6$ X 0,977) $+(0,3$ X 0,955) $+(0,1$ X

$=(0,5862+0,2865+0,0956)=0.9683$

Dwi Laksana

$0,934)\}$

$=\{(0,6$ X 0,965) $+(0,3$ X 0,977) $+(0,1 X$

$=(0,579+0,2931+0,0934)=0,9655$

Oka Oktarine

$0,956)\}$

$=\{(0,6$ X 0,988) $+(0,3$ X 0,944) $+(0,1 X$

$=(0,5928+0,2832+0,0956)=0,9716$

Resa Gemilang

$=\{(0,6$ X 1) $+(0,3$ X 0,944) $+(0,1$ X 0,934) $\}$

$=(0,6+0,2832+0,0934)=0,9766$

Dari perhitungan di atas ditemukan hasilnya sebagai berikut:

Ranking 1 : Arif Syarifudin

Ranking 2 : Resa Gemilang

Ranking 3 : Oka Oktarine

Sehingga dapat disimpulkan bahwa nilai terbesar diperoleh oleh Arif Syarifudin sebagai alternatif terbaik dengan nilai 0,979.

\subsection{ERD ( Entity Relationship Diagram )}

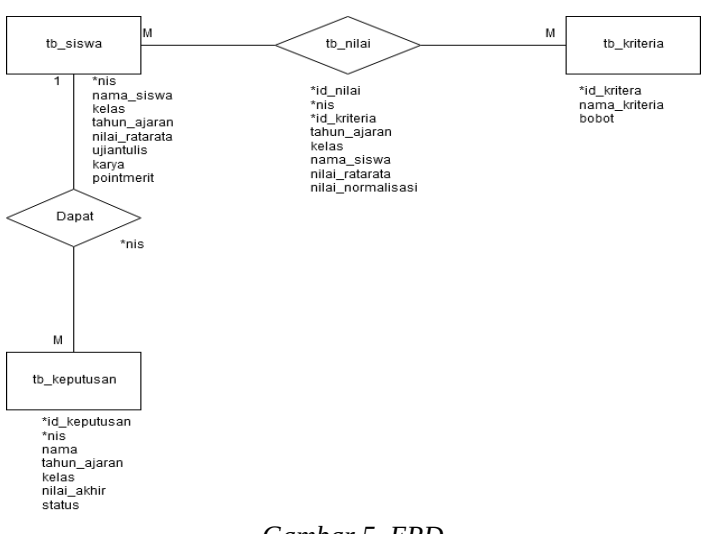

Gambar 5. ERD

\subsection{LRS ( Logical Record Structure )}

Pada gambar LRS di bawah ini dapat dilihat sebagai berikut.

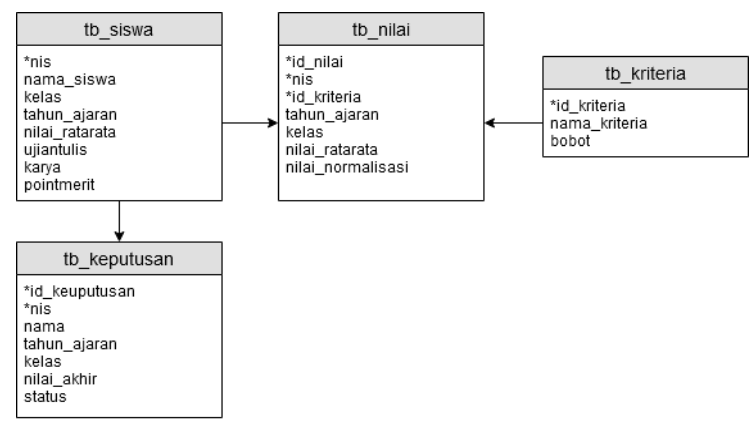

Gambar 6. LRS

\subsection{Usecase}

a. Usecase Input

Berikut ini adalah usecase input yang dapat dilihat gambar 7 sebagai berikut.

Input

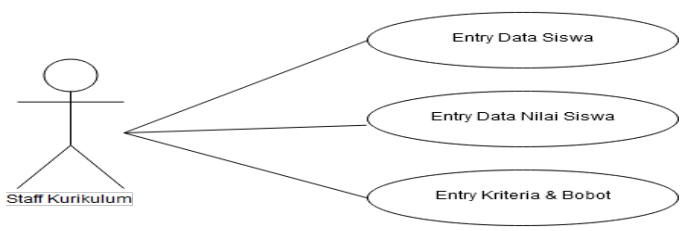

Gambar 7. Use Case Input

b. Usecase Proses

Berikut ini adalah usecase proses yang dapat dilihat gambar 8 sebagai berikut.

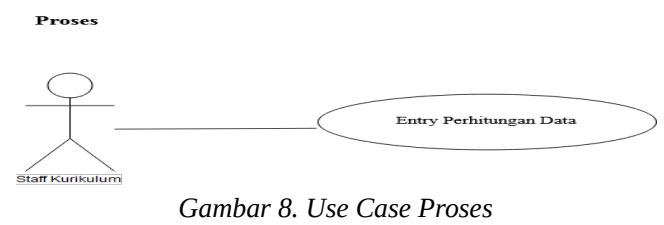

c. Usecase Laporan

Berikut ini adalah usecase laporan yang dapat dilihat gambar 9 sebagai berikut.

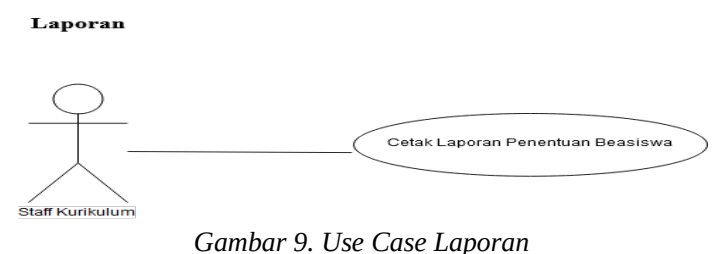

\subsection{Tampilan Halaman Sistem Penilaian} Kinerja Karyawan

a. Tampilan Halaman Login User

Pada gambar 10 di bawah ini adalah tampilan dari halaman login user yang dapat digunakan untuk 
login user ke sistem.

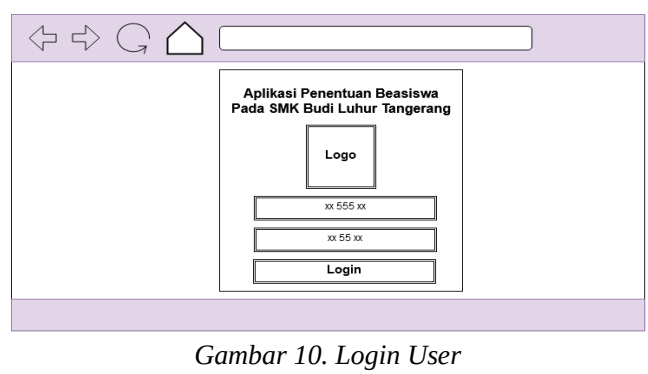

b. Tampilan Halaman Utama

Pada gambar 11 adalah tampilan halaman utama yang digunakan untuk melihat menu.

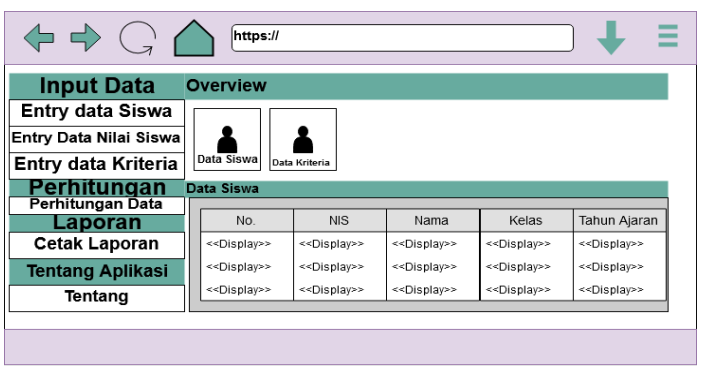

Gambar 11. Halaman Utama

Pada rancangan layar Halaman Utama ini adalah halaman utama ketika pengguna berhasil login, didalamnya terdapat 6 menu, yaitu Entri Data Siswa, Entri Nilai Siswa, Data Kriteria, Hitung Data, Laporan, serta Tentang.

c. Tampilan Entry Data Siswa

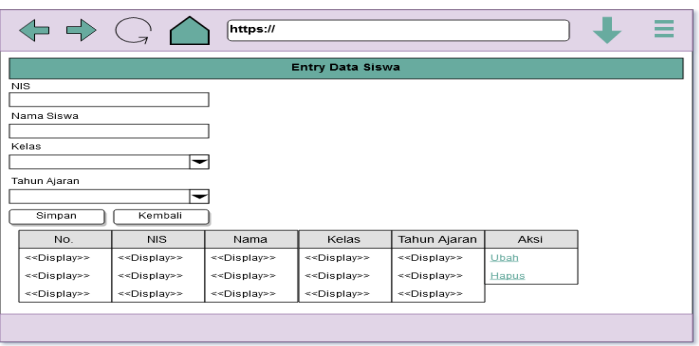

Gambar 12. Entry Data Siswa

Pada gambar rancangan layar Form Entri Data Siswa, user dapat memasukkan data siswa berupa NIS, nama siswa, serta tahun ajaran. di dalam form ini memiliki tombol submit untuk menyimpan data dan tombol kembali untuk kembali ke halaman sebelumnya. Di dalam form ini juga memiliki tabel tempat tampilnya data yang sudah disimpan ada button ubah untuk mengubah atau mengedit data yang telah tersimpan serta button hapus untuk menghapus data.

d. Tampilan Entry Data Nilai Siswa

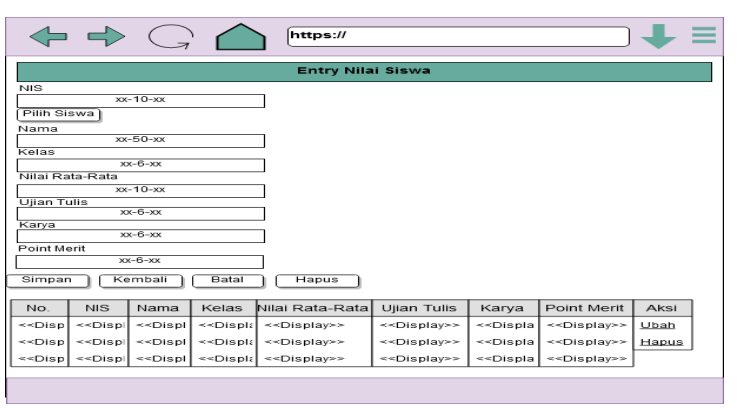

Gambar 13. Entry Nilai Siswa

Pada gambar rancangan layar Form Entri Data Siswa diatas ini user bisa memasukkan nilai siswa yakni dengan memencet tombol pilih siswa maka akan tampil list data siswa, lalu user dapat memilih siswa yang ingin diberikan nilai, kemudian user bisa memasukkan nilai siswa pada nilai rata-rata, ujian tulis, karya, serta point merit. Pada form entri nilai siswa ini mempunyai 4 tombol yakni tombol pilih siswa untuk memilih siswa yang akan diberikan nilai, button simpan untuk disimpan data nilainya, button ubah untuk mengubah data serta button kembali untuk kembali ke halaman sebelumnya.

\section{e. Tampilan Entry Data Kriteria}

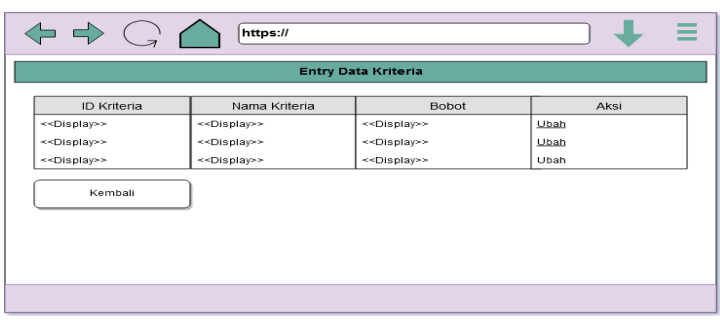

Gambar 14. Entry Data Kriteria

Pada rancangan layar Form Entri Data Kriteria ini terdapat tabel berisikan data kriteria dan bobot kriteria, pengguna dapat mengubah bobot kriteria dengan menekan button ubah untuk menuju ke form edit kriteria dan button kembali untuk kembali ke Form Home.

f. Tampilan Perhitungan Data

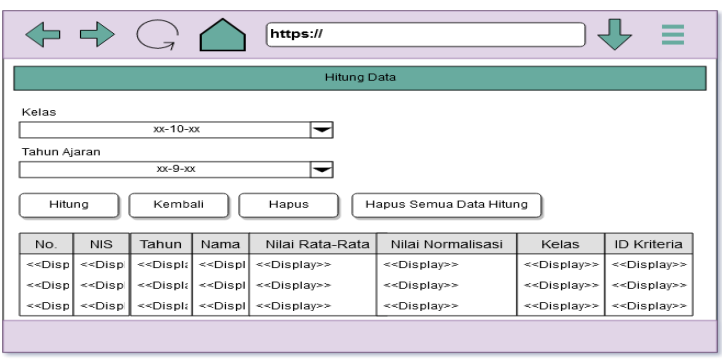

Gambar 15. Perhitungan Data

Pada gambar rancangan layar Form Hitung ini merupakan dimana perhitungan simple additive weighting (SAW) dipakai. User bisa memilih tahun 
ajaran serta kelas, setelah itu user menekan button hitung maka akan tampil skor perhitungan pada tabel yang sudah tersedia, menekan button hapus untuk menghapus isi dari tabel hitung dan jika ingin kembali ke halaman sebelumnya user dapat menekan button kembali.

\section{g. Tampilan Laporan}

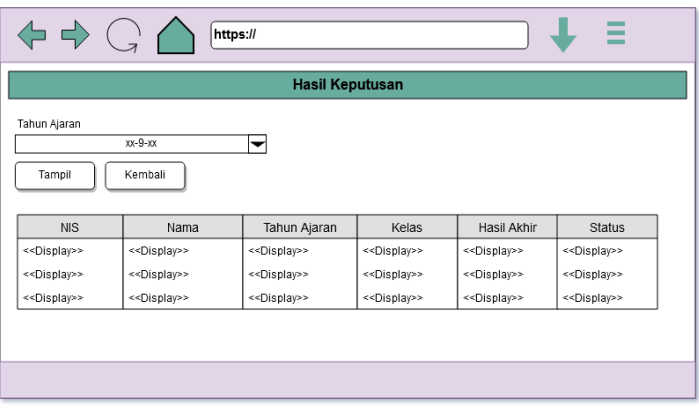

Gambar 16. Entry Hasil Keputusan

Pada gambar rancangan Form Laporan diatas ini user bisa memilih tahun ajaran serta memilih kelas yang ingin ditampilkan laporan hasil datanya. Di form ini memiliki 2 tombol yakni button tampil untuk memuncilkan laporan,dan button kembali untuk kembali ke halaman sebelumnya.

\subsection{Sequence Diagram}

a. Sequence Diagram Entry Data Siswa

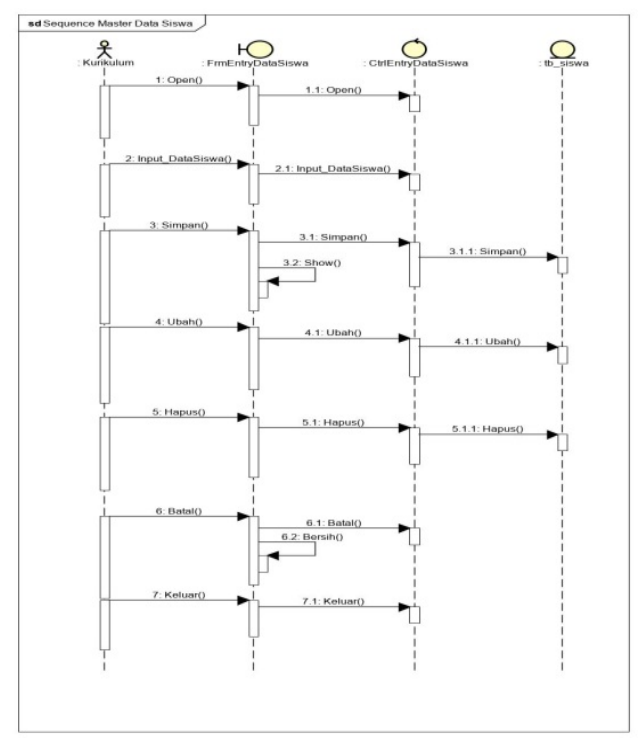

Gambar 17. Entry Data Siswa

Pada Gambar 17 menggambarkan sequence diagram kepada staff kurikulum yang melakukan proses entry data siswa.

b. Sequence Diagram Entry Data Nilai Siswa

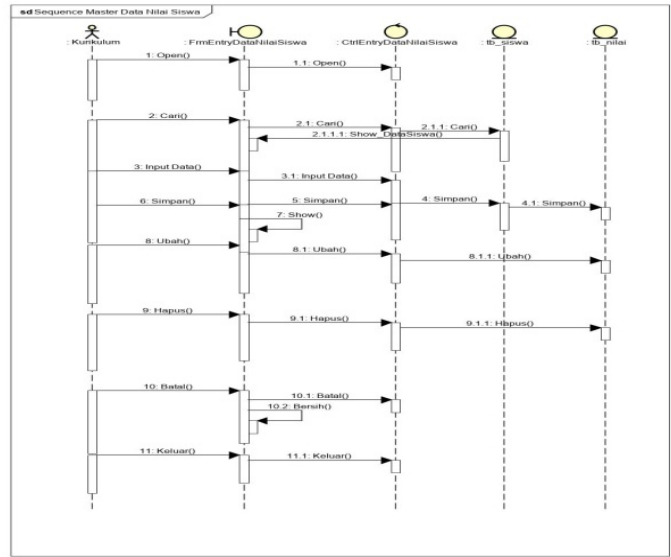

Gambar 18. Entry Data Nilai Siswa

Pada Gambar 18 menggambarkan sequence diagram kepada staff kurikulum yang melakukan proses entry data nilai siswa.

c. Sequence Diagram Entry Data Kriteria

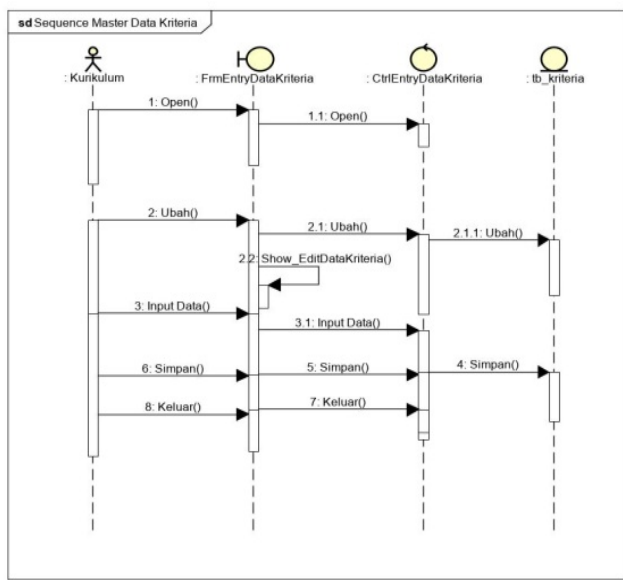

Gambar 19. Entry Data Kriteria

Pada Gambar 19 menggambarkan sequence diagram kepada staff kurikulum yang melakukan proses entry data kriteria.

d. Sequence Diagram Perhitungan Data

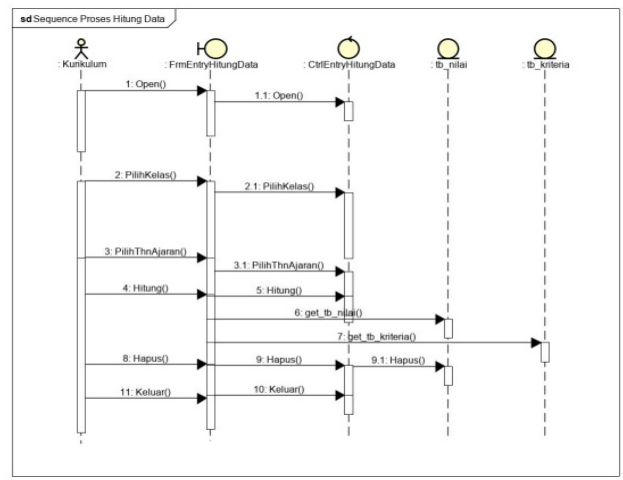

Gambar 20. Perhitungan Data 
Pada Gambar 20 menggambarkan sequence diagram kepada staff kurikulum yang melakukan proses hitung data.

e. Sequence Diagram Laporan hasil Keputusan

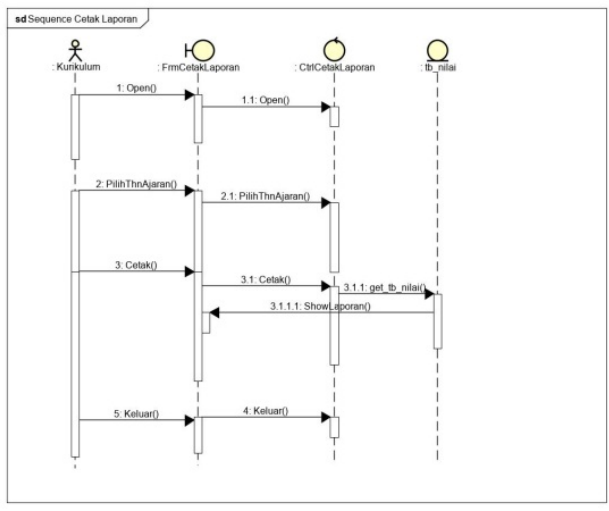

Gambar 21. Laporan Hasil Keputusan

Pada Gambar 21 menggambarkan sequence diagram kepada staff kurikulum yang melakukan proses entry data hasil keputusan.

\section{KESIMPULAN}

Berdasarkan kesimpulan yang didapat dari hasil penelitian pada SMK BUDI LUHUR adalah sebagai berikut

a. Dengan memiliki sistem penunjang keputusan ini, dapat membantu atau meringankan Kepala Sekolah dan Bidang Kurikulum SMK Budi Luhur Tangerang dalam penentuan beasiswa.

b. Karena adanya metode Simple Additive Weighting (SAW) sebagai cara penilaian penentuan beasiswa dengan nilai kriteria yang sudah ada sebelumnya. Sehingga proses penentuan beasiswa lebih tepat dan meminimalkan dari adanya subjektifitas dalam proses penentuan beasiswa.

c. Dengan memiliki database pada sistem penunjang keputusan bisa mempermudah atau meringankan pihak sekolah dalam mengolah data dan bisa dilakukan dengan efisien, akurat dan cepat.

\section{DAFTAR PUSTAKA}

[1] Turban, Decision Support Systems and Intelligent Systems ( Sistem pendukung keputusan dan system cerdas ) Jilid 1, Andi Offset, Yogyakarta, 2010.

[2] Yuliawan, Y., Sunarto, M. J. D. and Soebijono, T, 'Pengembangan Sistem Informasi Pendataan Jemaat Gereja Masehi Advent Hari Ketujuh Konferens Jawa Kawasan Timur Berbasis Web', Jurnal Sistem Informasi, 3(1), 2014, pp. 140-143. doi: 2338-137X.
[3] (2014) Jeperson Hutahaean, Konsep Sistem Informasi. yogyakarta: deepublish. Available at: http://bit.ly/2mlDLZF.

[4] (2014) Novriansyah, D, Konsep Data Mining Vs Sistem Pendukung Keputusan. yogyakarta: deepublish. Available at: https://bit.ly/2DJWKEj.

[5] (2016)http://nurainun9495.blogspot.com/2016/05/ pengertian-metode-simple-additive.htm

[6] Bernadus V.C., Henny I., and Nurtiana H, Fuzzy Multi-Atribute Decision Making (FUZZY MADM) Dengan Metode SAW Untuk Pemilihan Mahasiswa Berprestasi, 2017.

[7] Ipnuwati Sri, Pendukung Keputusan Pemberian Sanksi Pelanggaran Kedisiplinan Siswa Pada SMK PGRI I KEDONDONG, 2014. 